\title{
An Overview: Coronaviruses in Recent Two Decades
}

\author{
Mohammed H. Al-Mashhadani ${ }^{1}$, Alaa Mohammed ${ }^{1}$, Rasha Raheem² and Emad Yousif ${ }^{1, *}$ \\ ${ }^{1}$ Department of Chemistry, College of Science, Al-Nahrain University, Baghdad, Iraq \\ ${ }^{2}$ Department of Pathology, Microbiology and Immunology, University of South Carolina School of Medicine, \\ Columbia, SC, United States of America
}

\begin{tabular}{|c|c|}
\hline Article's Information & Abstract \\
\hline $\begin{array}{l}\text { Received: } \\
\text { 27.01.2021 } \\
\text { Accepted: } \\
\text { 23.02.2021 } \\
\text { Published: } \\
\text { 23.04.2021 }\end{array}$ & $\begin{array}{l}\text { Coronaviruses are an association of viruses which lead sicknesses in mammals } \\
\text { and birds. The Common symptoms that affect humans are respiratory tract } \\
\text { infections, fever, headache, etc. In this review, we highlight the development in } \\
\text { coronaviruses in recent two decade, which include simple acute respiratory } \\
\text { syndrome }(2002-2003) \text {, middle east respiratory syndrome (2012) and coronavirus } \\
\text { disease } 2019(2019-2020) \text {. }\end{array}$ \\
\hline $\begin{array}{l}\text { Keywords: } \\
\text { Coronaviruses } \\
\text { COVID-19 } \\
\text { WHO } \\
\text { SARS } \\
\text { MERS }\end{array}$ & \\
\hline
\end{tabular}

DOI: $10.22401 /$ ANJS.00.5.03

${ }^{*}$ Corresponding author: emad_yousif@hotmail.com

\section{Introduction}

In the 1930, coronavirus was discovered in the chickens when it caused severe respiratory infection. In the early 1960s, the first human infection case by coronaviruses (HCoV) was discovered [1]. Coronaviruses are a virus type which returen to Nidovirus superfamily, that could be included of enveloped plus-stranded (+RNA) viruses and presently as well includes the Arteriviridae, Roniviridae, and Mesoniviridae groups. They were divided into three groups, (HCoV-229E and HCoV-NL63), (no human CoVs as yet), and (HCoVOC43 and HCoV-HKU1), basically, rely on antigenic reactivity [2,3].

Figure 1 shows the structure of coronavirus, which has three main proteins. The spike protein or S-protein is quite large glycoprotein which makes bulky peplomers between 15 to $20 \mathrm{~nm}$. The second protein is N-protein (nucleocapsid protein) and the last one is M-protein (membrane protein). Moreover, some coronaviruses have E-protein and HEprotein see Figure $1[4,5]$.

Coronaviruses were found in many wildlife animals such as rodents, rabbits and bats. For humans, the virus causes acute respiratory infection including the common cold due to coronaviruses represent spectrum of viruses which can infect humans. For instant Middle East respiratory syndrome (MERS) and severe acute respiratory syndrome (SARS) are diseases that transferred to humans from animals [6,7]. On Jan 20, 2020, a patient from Wuhan, China, after he had a whole day of fever, was identified with coronavirus (COVID-19) by using RT-PCR sputum samples got from Central Hospital of Wuhan [8]. In this short review we highlight the evaluation of the corona virus in two decades and study of symptoms with recommendations necessary to prevent its spread.

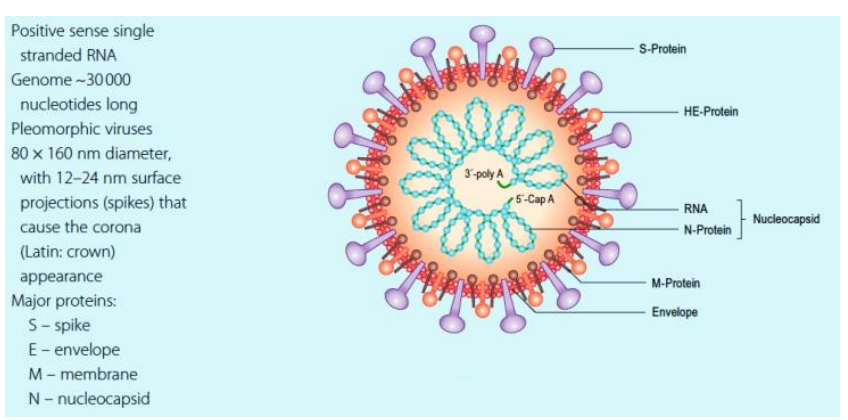

Figure 1. Structure of coronavirus.

\section{Severe Acute Respiratory Syndrome (SARS)}

From southern China and spread throughout the world with quantifiable speed, [9,10]. Beniac's group was grown coronavirus (SARS) in Vero E6 cells in BSL3 containment and iodoxanol gradient centrifugation was used to purify the virus. The $\mathrm{N}$ and $\mathrm{S}$ proteins were identified from pure fractions by western blotting. Figure 2 shows TEM images for SARS coronavirus and the images show that the virus is spherical, with an average diameter about $90 \mathrm{~nm}$ [11]. 


\section{Al-Nahrain Journal of Science}

Special Issue: COVID-19, April 2021, pp. 13-16
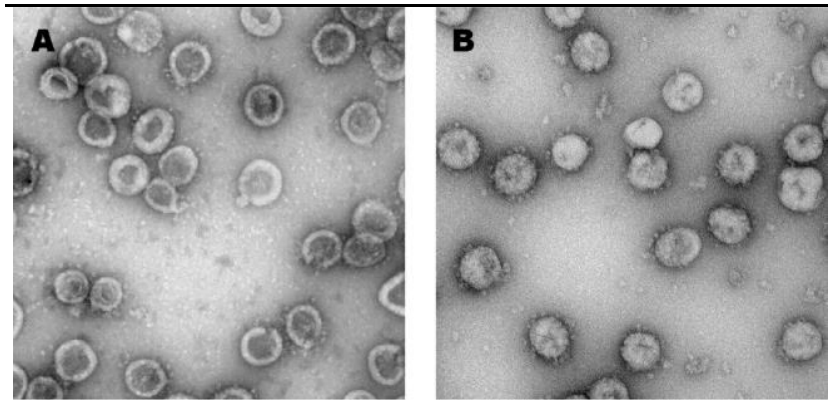

Figure 2. TEM images of SARS coronavirus.

As shown in Figure 3 [12], SARS has an incubation period of 2-7 days [13]. SARS virus has been found to replicate rapidly and produces large numbers of extract virus particles between 12 and 15 hours after infection [14].

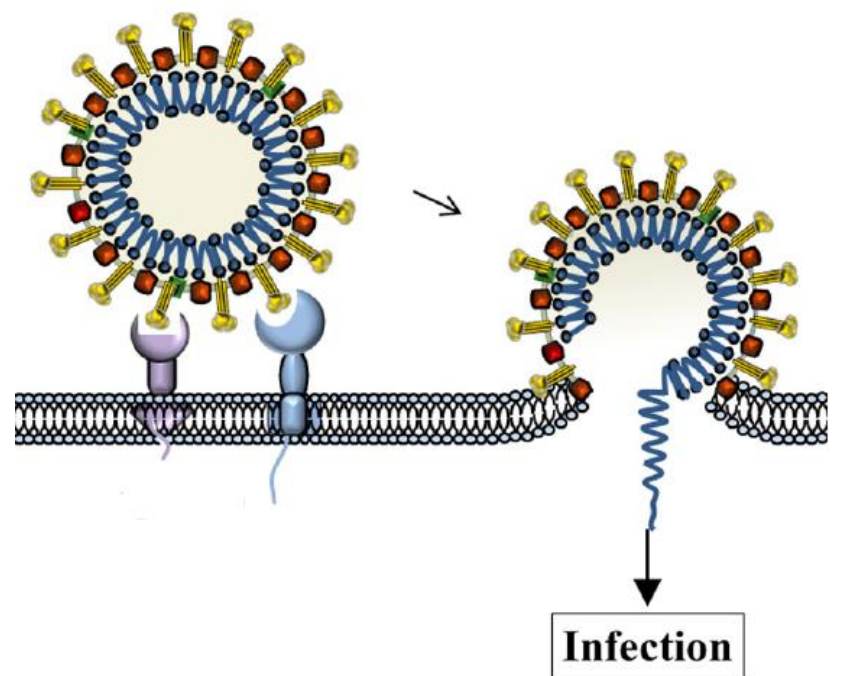

Figure 3. Routes employed by the SARS-coronavirus for entry into target cells.

\section{Middle East Respiratory Syndrome (MERS)}

The virus entered Saudi Arabia in June 2012 and spread to other African regions, Asia, America and Europe. MERS has been linked to high respiratory rates, multiple sclerosis, and high mortality. For those who do experience symptoms, the incubation period is about 2 to 14 days. The first possible unexplained symptom is pneumonia [16]. The effects of coronavirus respiratory failure in the Middle East were assessed by computed tomography (CT) and radiography of coronavirus patients. MERS infection 69 years before the heart X-ray showed that on day 1 of MERS, the unilateral upper limb was central in the upper right corner and the inner vitreous body in the lower right corner (Figure 4.A). After five days, two airways appeared in both lungs, indicating disease (Description 4.b). On day eight, the left side saw medium or medium noise, indicating additional damage (Figure 4.C) [17].

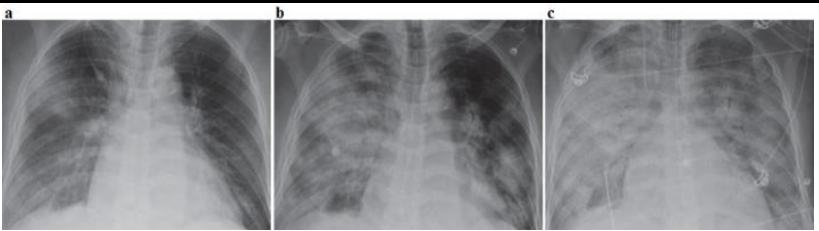

Figure 4. Chest radiologics for an 69-year-old man with MERS-CoV.

\section{Computed tomography (CT) radiograph (Figure 5) [18].}

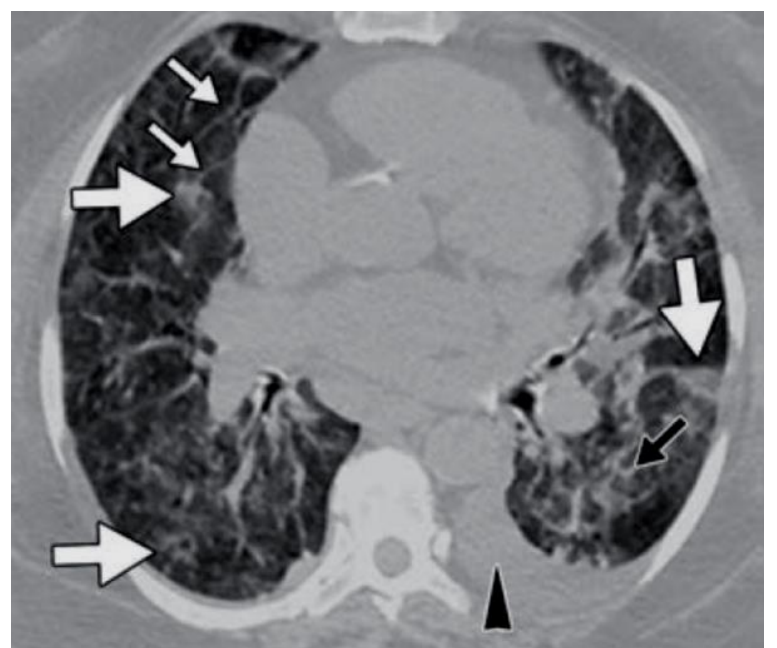

Figure 5. CT radiograph of 65-year-old woman with (MERS) coronavirus.

\section{Coronavirus Disease 2019 (COVID-19)}

This disease produced spread out quickly world, resulting) to deliberate it a pandemic [19,20, a]. Novel coronavirus disease (COVID-19) happened in Wuhan, Hubei Province, China spreading quickly to other sections of China [21]. Clinical performance of COVID-19 significantly brings to mind viral pneumonia for instance SARS and MERS. About $80 \%$ of the cases are moderate hence they have light symptoms and they recovered in 14 days. Few patients have severe symptoms which developed quickly having acute respiratory distress syndrome then unfortunately ended with organ failure [22, C]. Whereas the common symptoms [b]. On 24th of January 2020, a man with 37 years old was suffering from cough and expectoration after that he went under a chest CT examination as shown in Figure 6. The result of the examination demonstrated. He stayed in hospital for the same day and they did RT-PCR test for him which showed positive result. The lesion number and density was increased significantly on the CT images for both 27th of January and 2nd of February, particularly in both lower lobes. On both 4th and 7th of February RT-PCR tests were done and showed negative results and that was in agreement with CT examination as can be seen from CT images (see Figure 6) for 7th of February that was decreased. On the 15 th of the same month, the CT examination demonstrated that [23]. 


\section{Al-Nahrain Journal of Science}

Special Issue: COVID-19, April 2021, pp. 13-16

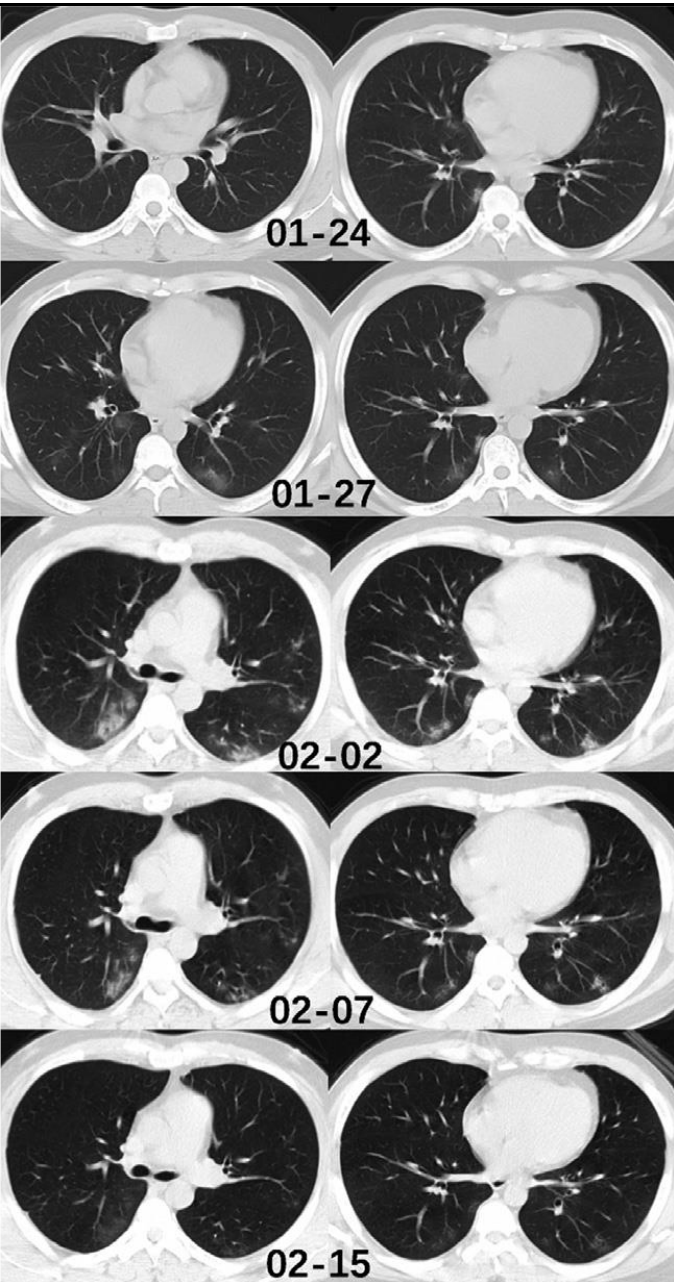

Figure 6. Chest CT of patient with COVID-19.

\section{Health Care Background}

The WHO shows the role of the social distancing and maskwearing can be the primary protection strategies to prevent the disease from developing the community transmission pattern, where the transmission classification is based on a process of country/territory/area self-reporting. Developing the transmission from Sporadic cases to Clusters of cases to community transmission is an indicator of the inadequate practice of social distancing in the countries who decided to reopen, and it represents a failure of the quarantine in the countries who decided to stay close [24-26].

\section{Conclusion}

As explained, the several viruses belong to the coronavirus family were cause diseases in mammals and birds with various symptoms. As the years progress, the viruses develop further, as we observe the COVID-19 causing more severe symptoms and respiratory damage in the end, leading to death in many cases. These viruses spread rapidly which leading the World Health Organization (WHO) to consider it a pandemic. Therefore, care must be taken in the future when dealing with animals carrying these viruses, strengthening the immune system and following the instructions of the World Health Organization.

\section{Acknowledgments}

This project is supported by Al-Nahrain University.

\section{Conflicts of Interest}

The authors declare no conflict of interest.

\section{References}

[1] Peiris J. S. M.; "Coronaviruses. In Medical Microbiology, 18th ed."; Greenwood D.; Barer M.; Slack R.; Irving W. Eds., Elsevier, 587-593, 2012.

[2] Weiss S. R. and Leibowitz J. L.; "Coronavirus Pathogenesis"; In Advances in Virus Research, Elsevier, 85-164, 2011.

[3] Snijder E. J. and Decroly E.; Ziebuhr, J.; "The Nonstructural Proteins Directing Coronavirus RNA Synthesis and Processing", Advances in Virus Research, 96, 59-126, 2016.

[4] Burrell C. J.; Howard C. R.; Murphy and F. A.; "Coronaviruses. In Fenner and White's Medical Virology, 5th ed.”; Burrell C. J.; Howard C. R.; Murphy F. A. Eds., Elsevier, 437-446, 2016.

[5] Korsman S. N. J.; Zyl G. U.; Nutt L.; Andersson M. I., Preiser W.; "Virology", Elsevier, 94-95, 2012.

[6] MacLachlan N. J. and Dubovi E. J.; "Coronaviridae. In Fenner's Veterinary Virology”, 5th ed.; MacLachlan N. J.; Dubovi E. J. Eds., Elsevier, 435-461, 2017.

[7] Al-Dahhan W. H.; Al-Mashhadani M. H.; Raheem R. and Yousif E.; "Iraq faces the COVID-19 with limited health capabilities and major medical challenges"; Revista Bionatura, 5(3), 1271-1274, 2020.

[8] Zhou C.; Gao C.; Xie Y. and Xu M.; "COVID-19 with spontaneous pneumomediastinum", The Lancet Infectious Diseases, 20, 510, 2020.

[9] Balboni A.; Palladini A.; Bogliani G. and Battilani M. "Detection of a virus related to betacoronaviruses in Italian greater horseshoe bats", Epidemiol. Infect., 139, 216-219, 2011.

[10] Kahn J. S. and McIntosh K.; "History and Recent Advances in Coronavirus Discovery", The Pediatric Infectious Disease Journal, 24, S223-S227, 2005.

[11] Beniac D. R.; Andonov A.; Grudeski E. and Booth T. F. "Transmission Electron Microscopy of the SARS Coronavirus", Microscopy Society of America, 12, 348-349, 2006.

[12] Simmons G.; Zmora P.; Gierer S.; Heurich A. and Pöhlmann, S.; "Proteolytic activation of the SARScoronavirus spike protein: Cutting enzymes at the cutting edge of antiviral research", Antiviral Research, 100, 605-614, 2013.

[13] Kudesia G. and Wreghitt T.; "SARS CoV and other coronaviruses. In Clinical and Diagnostic Virology", Cambridge: Cambridge University Press, 113-115, 2009. 


\section{Al-Nahrain Journal of Science}

Special Issue: COVID-19, April 2021, pp. 13-16

[14] Ng M. L.; Tan S. H.; Lee J. W. M.; Leong, M. L. N. and Tan, Y. J.; "Host cell changes induced during Severe Acute Respiratory Syndrome (SARS) coronavirus infection", Microscopy Society of America, 11, 996-997, 2005.

[15] Morbidity and Mortality Weekly Report, Nationwide Rubella Epidemic-Japan, 62, 457-486, 2013.

[16] Brunette G. W. and Nemhauser J. B.; "Travel-Related Infectious Diseases”. In CDC Yellow Book 2020, Oxford University Press, 169-394, 2019.

[17] Das K. M.; Lee E. Y.; Al Jawder S. E.; Enani M. A.; Singh R.; Skakni L.; Al-Nakshabandi N.; Al-Dossari K. and Larsson, S. G.; "Acute Middle East Respiratory Syndrome Coronavirus: Temporal Lung Changes Observed on the Chest Radiographs of 55 Patients", AJR, 205, W267-W247, 2015.

[18] Das K. M.; Lee E. Y.; Enani M. A.; Al-Jawder S. E.; Singh R.; Bashir S.; Al-Nakshbandi N.; Al-Dossari K. and Larsson S. G.; "CT Correlation with Outcomes in 15 Patients with Acute Middle East Respiratory Syndrome Coronavirus", AJR, 204, 736-742, 2015.

[19] Rezaei N.; "COVID-19 affects Healthy Pediatricians more than Pediatric Patients", Infection Control \& Hospital Epidemiology, 1, 2020.

[20] Wong S. C. -Y.; Kwong R. T. -S.; Wu T. C.; Chan J. W. M.; Chu M. Y.; Lee S. Y.; Wong H. Y. and Lung D. C.; "Risk of nosocomial transmission of coronavirus disease 2019: an experience in a general ward setting in Hong Kong”, Journal of Hospital Infection, 105, 119-127, 2020.

[21] Al-Mashhadani M. H.; Alsayed R.; Hussain Z.; Salih N. and Yousif E.; "An Overview of Possible Therapeutic Approaches Against Novel Coronavirus Disease 2019 Pandemic", Al-Nahrain Journal of Science, 6-11, 2020.

[22] Zhou F.; Gao X.; Li M. and Zhang Y.; "Shelter hospital: glimmers of hope in treating COVID-19", Disaster Medicine and Public Health Preparedness, 12, 2020.

[23] Xie M. and Chen Q. "Insight into 2019 novel coronavirus-an updated intrim review and lessons from SARS-CoV and MERS-CoV, IJID”, 94, 119124, 2020.

[24] Hadi A. G.; Kadhom M.; Hairunisa N.; Yousif E. and Mohammed S. A. "A Review on COVID-19: Origin, Spread, Symptoms, Treatment, and Prevention", Biointerface Research in Applied Chemistry, 10, 7234- 242, 2020.

[25] Alsayed R.; Kadhom M.; Yousif E. and Sabir D. K.; "An Epidemiological Characteristic of the COVID-19 Among Children", Biointerface Research in Applied Chemistry, 9, 1156-1164, 2020.

[26] Yang W.; Cao Q.; Qin L.; Wang X.; Cheng Z.; Pan A.; Dai J.; Sun Q.; Zhao F.; Qu J. and Yan F.; "Clinical characteristics and imaging manifestations of the 2019 novel coronavirus disease (COVID-19): A multi- center study in Wenzhou city, Journal of Infection", 80, 388-393, 2020.

[27] World Health Organization, Clinical management of severe acute respiratory infection when novel coronavirus (2019-nCoV) infection is suspected. Interim guidance, 28 January 2020.

[28] World Health Organization, Coronavirus disease 2019 (COVID-19) Situation Report-32, 21 February 2020.

[29] Association for Professionals in Infection Control and Epidemiology, Coronavirus Disease (COVID-19), 27 February 2020. 